Crisis Style 


\section{Crisis Style}

The Aesthetics of Repair

Michael Dango 
STANFORD UNIVERSITY PRESS

Stanford, California

(C)2022 by the Board of Trustees of the Leland Stanford Junior University. All rights reserved.

A section of Chapter 2 was originally published as "Minimalism as Detoxification," in MFS:

Modern Fiction Studies 65, no. 4 (2019): 643-675 @2019, Purdue University. Reprinted with permission.

An early version of Chapter 3 was originally published as "Filtering: Theory and History of a Style," in New Literary History 51, no. 1 (2020): 177-207 @2020, Johns Hopkins University Press. Reprinted with permission.

No part of this book may be reproduced or transmitted in any form or by any means, electronic or mechanical, including photocopying and recording, or in any information storage or retrieval system without the prior written permission of Stanford University Press.

Printed in the United States of America on acid-free, archival-quality paper

Library of Congress Cataloging-in-Publication Data

Names: Dango, Michael, author.

Title: Crisis style : the aesthetics of repair / Michael Dango.

Other titles: Post 45.

Description: Stanford, California : Stanford University Press, 2022.| Series: Post 45 |

Includes bibliographical references and index.

Identifiers: LCCN 2021005330 (print) | LCCN 2021005331 (ebook) | ISBN 9781503615052 (cloth) | ISBN 9781503629554 (paperback) | ISBN 9781503629561 (ebook)

Subjects: LCSH: Aesthetics, American-2oth century. | Aesthetics, American-21st century. |

Arts, American-2oth century. | Arts, American-21st century. | Arts, Modern-Philosophy.

Classification: LCC BH221.U53 $\mathrm{D}_{3} 62 \mathrm{O} 21$ (print) | LCC BH221.U53 (ebook) |

DDC 701/.170973-dc23

LC record available at https://lccn.loc.gov/2021005330

LC ebook record available at https://lccn.loc.gov/2021005331

Cover design: Kevin Barrett Kane

Cover photo: Mehdi Sepehri

Typeset by Kevin Barrett Kane in 10/15 Minion Pro 
In memory of my mother 
This page intentionally left blank 